\title{
A study on the mode of public participation in Chinese urban design under the concept of multi- body participation Community-building oriented with multi-age participation
}

\author{
Xiaoying LUAN, TJUPDI, China \\ Yi ZHANG, THUPDI, China
}

\begin{abstract}
With the society and economy of China entering the transition period, people's requirements for urban life show a trend of diversification and high standards. Urban design is no longer limited to physical space but starts to carry out multi-angle and multi-level comprehensive consideration on the social and spatial problems of symbiosis. In this context, the innovative social governance and the quality improvement of urban public space that highlights the role of the public have become hot topics. As the main body of city users, ordinary people entering into the deep and substantial participation from the superficial and symbolic is the only way for urban design to transform from the expert-led "optimal scheme" to the "reasonable scheme" recognized by pluralistic bodies. In the process of western democratic politics, the participation theory that focuses on the construction of micro democracy is prevalent, and the public participation based on pluralism has become the theoretical basis for the planning participation. Besides, the concept of communicative planning and collaborative planning, which emphasize cooperation and consultation, also enriches the connotation of multiple participation. Due to different systems and awareness, it is difficult to promote public participation under China's national conditions. Community building, the interdisciplinary product of urban design and social governance under communities, is regarded as the experimental field for participating in the reform. Therefore, under the current administrative system and regulations, this paper tries to make use of the grass-roots management mode with Chinese characteristics to establish an inclusive multi-participation mechanism. It allows residents of different ages can go deep into the process of community building by taking the family unit. Meanwhile, some suggestions and strategies are raised for effective participation. We hope the bottom-up process of urban design in microscale can be an effective instrument to reflect the public's will and repair social relations at the same time, while explore and solve urban problems in diverse cooperation.
\end{abstract}

\section{Keywords}

Public Participation, Multi-body Participation, Community Building, Social Governance, Chinese Characteristics. 


\section{Introduction}

With the high voice of the public participation since the 1980s, the civil society in western developed countries has grown rapidly, and the social governance model has begun to transfer from one-way control to interactive administration. This trend of democratization manifested in the field of urban planning as the interactive and consultative design of pluralism, which also becomes the theoretical basis of the multiple participation in the urban design process. After 40 years of reform and opening-up policy, China's rapid economic development and information globalization have promoted the awakening of citizens' consciousness and the promotion of civil society. The concept of social governance, such as diverse participation, consultation and co-governance, has also been widely recognized. The new urbanization makes the planning discipline shift from incremental to stock planning, and urban design also begins to change from the morphological design that emphasizes physical outcome to the social-spatial process that concentrates on diversification. The long-term government-dominated planning model has made serious "gentrification" in the process of urban construction and renewal in China, and it is difficult improved through top-down government actions under the existing political system. Therefore, turning to the practice study of community building at the micro-level is to meet the development trend of urban design, as well as is the realizable and feasible research of the multiple participation modes under the current system.

Compared with the developed country, China is still in the earlier stage with weak theory and practice in this field. This paper tries to find the research direction by summarizing foreign theoretical experience and domestic situation. It will explore the roles and relationships of diverse participants, and attempt to sort out a set of multiple participation mode suitable for Chinese conditions, from the perspective of community intervention under the current planning system. Among those patterns, community planner acts the facilitator of multiple interests and spokesman of residents to actively contribute to bottom-up community actions, allocate various social resources, and construct inclusive community intending to improve citizens' life. Giving full play to the self-governance power of community-level organizations and being able to engage in dialogue, even negotiating with the government will be the key to the successful design practice of community public participation.

\section{Exploration of the planning theory and practice direction of public participation}

\subsection{The planning theory and practice of public participation in western countries}

The theory of public participation in urban planning and design in the western world can be roughly divided into four stages: the post-World War II period (1950-1960s), the germination period (1960-1970s), the developing period (1970-1990s) and the mature period (1990-present). In 1994, the emergence of Communicative Planning Theory, marked that the public participation completed from the social movement to the direction of theory and institutionalization, and entered the mature stage. The focus of planning discipline has shifted from the object relations of modernism after the World War II and the humanism's subject relations in the 1960s, to the inter-subjective relations that the civil society and public space construction emphasis on after the 1990s. (See Table 1.)

\begin{tabular}{|c|l|l|l|l|}
\hline \multicolumn{1}{|c|}{ Stage } & \multicolumn{1}{c|}{ After WW II } & \multicolumn{1}{c|}{ Infancy } & \multicolumn{1}{c|}{ Growth } & \multicolumn{1}{c|}{ Maturity } \\
\hline Theory & Rational Planning & $\begin{array}{l}\text { Incremental } \\
\text { Planning }\end{array}$ & $\begin{array}{l}\text { Advocacy } \\
\text { Planning }\end{array}$ & $\begin{array}{l}\text { Communicative } \\
\text { Planning, }\end{array}$ \\
\hline
\end{tabular}




\begin{tabular}{|c|c|c|c|c|}
\hline & & & & $\begin{array}{l}\text { Collaborative } \\
\text { Planning }\end{array}$ \\
\hline Period & Before 1950s & During 1950s & $\begin{array}{l}\text { From } 1960 \text { s to } \\
1990 \mathrm{~s}\end{array}$ & From 1990s till now \\
\hline $\begin{array}{l}\text { Planning } \\
\text { Thinking }\end{array}$ & $\begin{array}{l}\text { Instrumental } \\
\text { rationality }\end{array}$ & $\begin{array}{l}\text { Bounded } \\
\text { rationality }\end{array}$ & $\begin{array}{l}\text { Critique on } \\
\text { rationalism, } \\
\text { empiricism, } \\
\text { Pluralism }\end{array}$ & $\begin{array}{l}\text { Communicative } \\
\text { rationality, } \\
\text { Pluralism }\end{array}$ \\
\hline $\begin{array}{l}\text { Political } \\
\text { Thinking }\end{array}$ & $\begin{array}{l}\text { Representative } \\
\text { democracy }\end{array}$ & $\begin{array}{l}\text { Representative } \\
\text { democracy }\end{array}$ & $\begin{array}{l}\text { Participative } \\
\text { democracy }\end{array}$ & $\begin{array}{l}\text { Participative } \\
\text { democracy, } \\
\text { Deliberative } \\
\text { democracy } \\
\end{array}$ \\
\hline Principle Part & $\begin{array}{l}\text { Subjective- } \\
\text { Objective }\end{array}$ & $\begin{array}{l}\text { Subjective- } \\
\text { Objective }\end{array}$ & Subjective & Inter-subjective \\
\hline $\begin{array}{l}\text { Planning } \\
\text { Essence }\end{array}$ & $\begin{array}{l}\text { Optimal action } \\
\text { plan: the optimal } \\
\text { scheme, } \\
\text { government }\end{array}$ & $\begin{array}{l}\text { Optimal action } \\
\text { plan: the optimal } \\
\text { scheme, } \\
\text { government }\end{array}$ & $\begin{array}{l}\text { Satisfying action } \\
\text { plan: the best } \\
\text { scheme for } \\
\text { public, self- } \\
\text { government }\end{array}$ & $\begin{array}{l}\text { Satisfying action } \\
\text { plan: the reasonable } \\
\text { scheme, co- } \\
\text { governance }\end{array}$ \\
\hline $\begin{array}{l}\text { Planning } \\
\text { Purpose }\end{array}$ & $\begin{array}{l}\text { Problem-solving, } \\
\text { general human } \\
\text { needs }\end{array}$ & $\begin{array}{l}\text { Problem-solving, } \\
\text { extending } \\
\text { selections and } \\
\text { those chances } \\
\text { during planning }\end{array}$ & $\begin{array}{l}\text { Sociality of } \\
\text { planning: } \\
\text { concerning on } \\
\text { interest of } \\
\text { grassroot }\end{array}$ & $\begin{array}{l}\text { Environment } \\
\text { learning, interest of } \\
\text { particular group }\end{array}$ \\
\hline $\begin{array}{l}\text { Planning } \\
\text { Foundation }\end{array}$ & Scientific principle & Scientific principle & $\begin{array}{l}\text { Coordinated } \\
\text { interest }\end{array}$ & $\begin{array}{l}\text { Understanding \& } \\
\text { consensus }\end{array}$ \\
\hline Operation & $\begin{array}{l}\text { Top-down } \\
\text { government action }\end{array}$ & $\begin{array}{l}\text { Top-down } \\
\text { government action }\end{array}$ & $\begin{array}{l}\text { Bottom-up } \\
\text { campaign }\end{array}$ & $\begin{array}{l}\text { Top-down \& bottom } \\
\text { up institutionalized } \\
\text { politics }\end{array}$ \\
\hline $\begin{array}{l}\text { Role of } \\
\text { Government }\end{array}$ & Dominator & Dominator & $\begin{array}{l}\text { Weakened } \\
\text { dominator }\end{array}$ & Leader \\
\hline Role of Public & Receiver & Receiver & $\begin{array}{l}\text { Strengthened } \\
\text { receiver }\end{array}$ & Participant \\
\hline Role of Planner & $\begin{array}{l}\text { Supporter for } \\
\text { decision-making }\end{array}$ & $\begin{array}{l}\text { Participant in } \\
\text { decision-making }\end{array}$ & Public spokesman & $\begin{array}{l}\text { Facilitator for } \\
\text { coordinating several } \\
\text { parties }\end{array}$ \\
\hline $\begin{array}{l}\text { Representative } \\
\text { Theory and } \\
\text { Publication }\end{array}$ & $\begin{array}{l}\text { Meyerson, (1956): } \\
\text { Rational } \\
\text { Comprehensive } \\
\text { Planning; } \\
\text { McLoughlin (1969): } \\
\text { System Approach } \\
\text { of Planning; } \\
\text { Andreas Faludi } \\
\text { (1973): Procedural } \\
\text { Planning Theory. }\end{array}$ & $\begin{array}{l}\text { Charles Lindblom } \\
\text { (1959): Disjointed } \\
\text { Incrementalism; } \\
\text { Etzioni (1967): } \\
\text { Mixed-Scanning }\end{array}$ & $\begin{array}{l}\text { Jane. J (1961): } \\
\text { The Death and } \\
\text { Life of Great } \\
\text { American Cities, } \\
\text { C. Alexander } \\
\text { (1965): A City is } \\
\text { Not A Tree, } \\
\text { Sherry. R. A } \\
\text { (1969): A ladder } \\
\text { of civic } \\
\text { engagement, } \\
\text { Davidoff } \\
\text { (1962/1965): A }\end{array}$ & $\begin{array}{l}\text { Sager (1994): } \\
\text { Communicative } \\
\text { Planning } \\
\text { Theory, } \\
\text { Healey (2003): } \\
\text { Collaborative } \\
\text { Planning } \\
\text { Theory. }\end{array}$ \\
\hline
\end{tabular}




\begin{tabular}{|l|l|l|l|}
\hline & & $\begin{array}{l}\text { Choice Theory } \\
\text { of Planning \& } \\
\text { Advocacy and } \\
\text { Pluralism in } \\
\text { Planning }\end{array}$ & \\
& & \\
\hline
\end{tabular}

Table 1. Summarizing list of participation theory in urban planning and design in the west world. Source: Long, 2003; Sun and Yin, 2004; Zhou, etc., 2017; author edited and added details.

From the perspective of the theoretical development and practice of public participation, pluralism is the ideological basis with constantly developing and enriching throughout the whole process. It represents the continuous advance of democratic politics and the continuous rise of people's rights. Under its influence, public participation in planning decision sprouted from Incremental Planning. A Choice Theory of Planning written by Davidoff and Reiner in 1962, became the theoretical basis for the construction of public participation in urban planning. The theory of Advocacy Planning advocates to extend selections and those chances during the planning, and encourages the grassroot to speak aloud for themselves. Meanwhile, planners should pay attention to the coordination of various interests, which is the beginning of the multiple participation concept. Then, further development of Communicative Planning is to seek a relationship of multilateral cooperation between the government, public, developers and planners under the premise of pluralism, and then reach an agreement: the most reasonable scheme through mutual consultation. Multiple participation is the democratic consciousness progress of the social value purpose from "fairness and justice" to "pluralistic tolerance", and it is also a significant way to embody and protect civil rights.

\begin{tabular}{|c|c|c|c|}
\hline Country & Time & Name of Practice & Core Content \\
\hline \multirow{4}{*}{$\begin{array}{l}\text { United } \\
\text { States }\end{array}$} & 1923 & Neighbourhood Unit & $\begin{array}{l}\text { It emphasizes that the material space design } \\
\text { of the community is helping to solve social } \\
\text { problems. Planners should not only pay } \\
\text { attention to space issues but also consider } \\
\text { social issues such as lack of community sense } \\
\text { and public participation. }\end{array}$ \\
\hline & 1941 & Urban Renewal Plan & $\begin{array}{l}\text { The method of rational and centralized use of } \\
\text { the scattered lands is provided, and the } \\
\text { measures of relieving traffic and building new } \\
\text { facilities. }\end{array}$ \\
\hline & $1960 \mathrm{~s}$ & Community Action Project & $\begin{array}{l}\text { Citizens were involved in the design and } \\
\text { implementation of the community } \\
\text { extensively, and to promote the } \\
\text { comprehensive community regeneration } \\
\text { through an integrated approach of social, } \\
\text { political, economic and spatial development, } \\
\text { instead of single physical form. }\end{array}$ \\
\hline & $1960 \mathrm{~s}$ & $\begin{array}{c}\text { Community Economic } \\
\text { Development }\end{array}$ & $\begin{array}{l}\text { Integrated community development planning } \\
\text { is no longer dominated by the relevant city } \\
\text { government, but is devolved to the }\end{array}$ \\
\hline
\end{tabular}




\begin{tabular}{|c|c|c|c|}
\hline & & & $\begin{array}{l}\text { development corporation that contacts the } \\
\text { community directly. }\end{array}$ \\
\hline & $1970 s$ & $\begin{array}{l}\text { Community planning } \\
\text { supported by the city } \\
\text { government }\end{array}$ & $\begin{array}{l}\text { The authority supported planning is more } \\
\text { practical, the influence of citizens in the } \\
\text { community planning is expanded, and social } \\
\text { capital is provided for the development of the } \\
\text { neighbourhood. }\end{array}$ \\
\hline & $1980 \mathrm{~s}$ & $\begin{array}{c}\text { Planning Unit of } \\
\text { Development (PUD), } \\
\text { Traditional Neighbourhood } \\
\text { Planning (TND), } \\
\text { Transit Oriented } \\
\text { Development (TOD) }\end{array}$ & $\begin{array}{l}\text { It began to focus on community design and } \\
\text { created community planning models that } \\
\text { encouraged walking, public transportation, } \\
\text { social interaction, and a sense of community. }\end{array}$ \\
\hline $\begin{array}{l}\text { United } \\
\text { Kingdom }\end{array}$ & $\begin{array}{l}\text { Middle of } \\
\text { 1980s }\end{array}$ & Community Architecture & $\begin{array}{l}\text { Officially sanctioned by government } \\
\text { departments and planning professionals, the } \\
\text { construction model concentrates on } \\
\text { population's participation, as well as the } \\
\text { shaping and operation of the own } \\
\text { environment. }\end{array}$ \\
\hline Japan & $1970 s$ & $\begin{array}{l}\text { Community environment } \\
\text { building (Machizukuri) }\end{array}$ & $\begin{array}{l}\text { Residents' participation is emphasized, and } \\
\text { the legal status of residents' organizations is } \\
\text { affirmed by the government and financially } \\
\text { supported. }\end{array}$ \\
\hline
\end{tabular}

Table 2. Practices of participation in urban planning and design from different countries. Source: Hao, 2013. Author edited and added details.

According to the pluralist thought, urban design is seeking dialogue existing in all kinds of group, interpreting different values, lifestyles and cultural traditions in the space level, or converting these contents into different space form, then establish a collaborative platform by consultations and negotiations (Sun and Yin 2004). Public participation in urban design is often showed as group participation. There are two main forms of it: one is community participation, the other is engaged through intermediary organizations. The aspect of participation often lies on social governance and place-making. Hence, it has empirical feasibility to experiment with the multi-participation on the community level.

\subsection{Current situation, exploration and opportunities of public participation in Chinese city}

\begin{tabular}{|l|l|l|}
\hline \multicolumn{2}{|c|}{ Stages in urban design process } & Content of public participation \\
\hline Designing phase & Design approval & Public announcement \\
\hline
\end{tabular}




\begin{tabular}{|l|l|l|}
\hline \multirow{2}{*}{} & $\begin{array}{l}\text { Value target determination } \\
\text { and scheme formation }\end{array}$ & Survey of public intension \\
\cline { 2 - 3 } & $\begin{array}{l}\text { Preliminary results } \\
\text { completion }\end{array}$ & Public review \\
\cline { 2 - 3 } & Design scheme censoring & Public hearing \\
\hline \multirow{2}{*}{ Executing phase } & Results Publication & Public display \\
\cline { 2 - 3 } & Scheme Implementation & Public supervision \\
\hline
\end{tabular}

Table 3. The phase of public participation in urban design. Source: Wang, 2006.

At present, the planning and construction in Chinese cities are still dominated by the way that the government-led and the urban designers' technical support, and the measures and implementation efforts of public participation do not show positive and powerful signs (Hao 2007). This traditional public decision process tends to focus on economic benefits rather than social equity, thus the elites with high rates of return are more likely benefited in the formulation and selection of strategies. The professional designers' values and social ideals are isolated and differentiated from the population, and the interests of the politically and economically disadvantaged groups are ignored. Secondly, the technical rationality led by design professionals has limitations. As a social discipline, urban design is not absolute rationality but influenced by subjective factors, the authority of experts can be questioned and become a tool to legitimize official decision-making. Therefore, the city planning and design scheme conducted by technical experts plays a limited job in realizing the value goal of public interests. Besides, although the authorities put forward the requirement of public participation in the design and decision process, most of them remain in the post-participation and passive participation. The process just stays on the information receiving and feedback, such as the public hearings and publicity of the outcome. The rare public supervision activities like petition are inefficient, hysteretic and lack of feedback. It belongs to the degrees of tokenism in the model of "A ladder of civic engagement" proposed by Arnstein (1969), which has no substantial help for scientific decision-making.

\begin{tabular}{|c|c|c|c|c|c|c|c|c|c|c|}
\hline & & \multicolumn{2}{|c|}{ Decision-making Branch } & \multicolumn{2}{|c|}{ Administrative Branch } & \multicolumn{2}{|c|}{ Technical Branch } & \multicolumn{3}{|c|}{ Non-government Institution } \\
\hline & & Policymakers & $\begin{array}{c}\text { planning } \\
\text { committee }\end{array}$ & $\begin{array}{c}\text { Urban } \\
\text { Design } \\
\text { Specialized } \\
\text { Institution }\end{array}$ & $\begin{array}{l}\text { City } \\
\text { Constructing } \\
\text { \& Planning } \\
\text { Department }\end{array}$ & $\begin{array}{l}\text { Urban Design } \\
\text { Technical } \\
\text { Institution }\end{array}$ & $\begin{array}{l}\text { Expert } \\
\text { Group }\end{array}$ & $\begin{array}{l}\text { Community } \\
\text { Organization }\end{array}$ & $\begin{array}{c}\text { NPO (non-for- } \\
\text { profit } \\
\text { organization } \\
1\end{array}$ & $\begin{array}{c}\text { Private } \\
\text { Enterprise }\end{array}$ \\
\hline \multirow{4}{*}{ Comprehensive Scheme } & Feasibility Analysis & & & & & & & & & \\
\hline & Determining Target & & & & & & & & & \\
\hline & $\begin{array}{l}\text { Planning Condition } \\
\text { Drawing Up } \\
\end{array}$ & & & & & & & & & \\
\hline & Work Plan Drawing Up & & & & & & & & & \\
\hline \multirow{5}{*}{ Design \& Compilation } & Investigating Research & & & & & & & & & \\
\hline & Collecting Opinion & & & & & & & & & \\
\hline & $\begin{array}{l}\text { Compilation \& } \\
\text { Achievement }\end{array}$ & & & & & & & & & \\
\hline & $\begin{array}{l}\text { Evaluation \& } \\
\text { Modification }\end{array}$ & & & & & & & & & \\
\hline & $\begin{array}{l}\text { Examination and } \\
\text { Approval }\end{array}$ & & & & & & & & & \\
\hline $\begin{array}{l}\text { Administration \& } \\
\text { Implementation }\end{array}$ & $\begin{array}{l}\text { Detailed Design \& } \\
\text { Implementation }\end{array}$ & & & & & & & & & \\
\hline
\end{tabular}




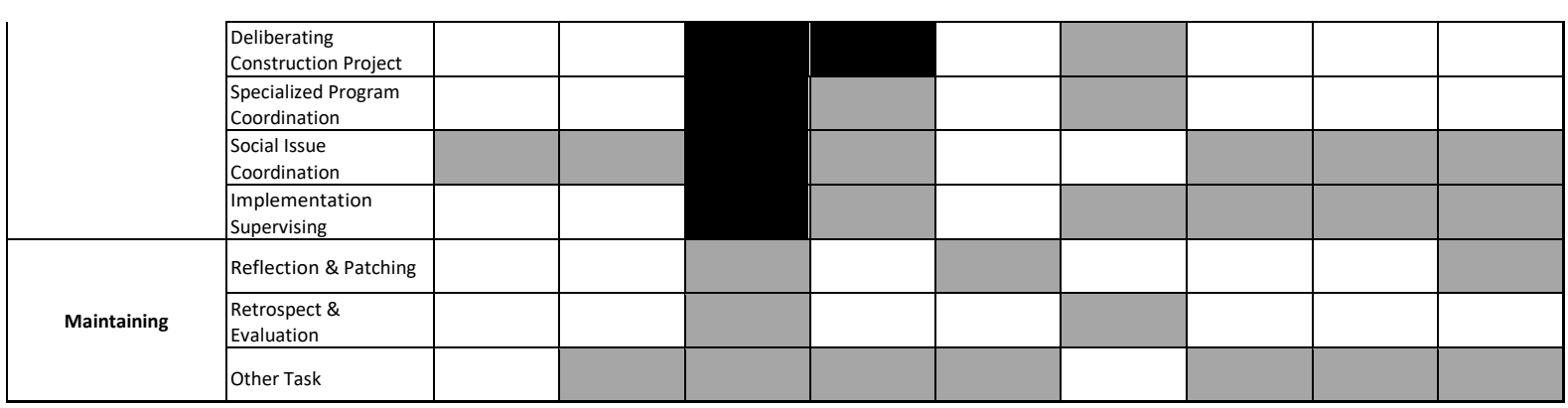

(Legend: strong participation, mediate participation, $\square$ weak participation.)

Table 4. The degree of participating in the overall urban design process against different teams in four kinds of main institutions. The "Non-government Institution" colour bars' situation contrast with the rest of institutions can show that insufficient condition of public participation in China. Source: Wang, 2006.

It can be seen that, as the receiver of urban design and construction, the citizens' participation right is asymmetric to the government's decision right, and it lacks a model and platform to guide it to effectively voice for public interests. Aim to overcome the authoritarianism that ignores the residents' welfares under the value measure of national rationality, the community building with collectivity and autonomy shall become a feasible breakthrough in the current system of China (Yu and Zhang 2002; Huang and Xu 2013). At present, the structure of community governance in Chinese cities is "unitary dominates pluralism": the governance of community public affairs is dominated by the government, but extensive taken part by multiple subjects like self-organization of communities and residents. By the combination of administrative regulation and autonomy mechanism, the complementation of government administration and community autonomy, an institutional guarantee for citizens' voluntary participation, community selforganization, and legal management of government is provided on the platform of community. The subdistrict office and the community self-organization represented by the neighbourhood committee begin to turn from "virtual body of power" to "real body of power". It is an important manifestation of the government's power descending to the grassroots level, and also an organizational platform for the real "citizen power" in Arnstein's the "A ladder of civic engagement" model (1969). Also, to reach a multirecognized value goal consensus based on the community is to cultivate group and even community awareness, which called "sense of ownership", on the premise of recognizing individual interests. This can establish the value goal orientation of public interests for urban design participation.

\begin{tabular}{|c|l|}
\hline \multirow{2}{*}{ Citizen Power } & Citizen Control \\
\cline { 2 - 2 } & Delegated Powder \\
\cline { 2 - 2 } & Partnership \\
\hline \multirow{2}{*}{ Tokenism } & Placation \\
\cline { 2 - 2 } & Consultation \\
\cline { 2 - 2 } & Informing \\
\hline Nonparticipation & Therapy \\
\cline { 2 - 2 } & Manipulation \\
\hline
\end{tabular}

Table 5. Eight ladders of public participation in A Ladder of Civic Engagement. Source: Arnstein, 1969. 


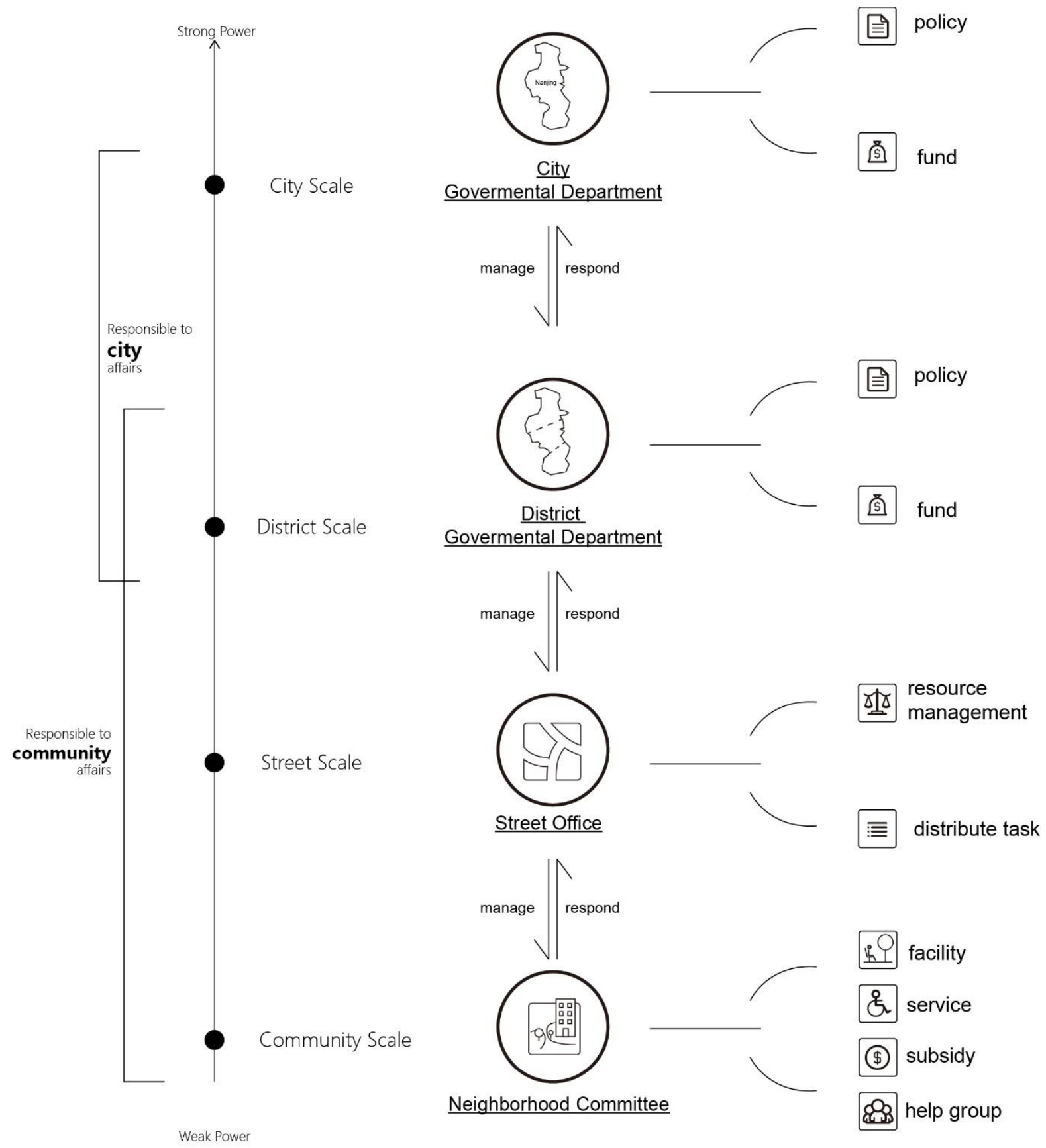

Figure 1. Administrative management system in China, a top-down model including information about their roles, functions and administrative scale. Source: author drew. 


\section{Analysis on the subjects of multiple participation}

\section{1. Horizontal research: Building up a new type of multiple subject relationship}

The urban design involves many participants, which can be divided into three categories according to their relations in the process, which include the government as the initiator, the professional designer as the executor, and the public as the beneficiary. Under the current system of China, the government, as the right department of planning and construction, is the leader and decision-maker of urban design, while the technical support department composed of the professional design team is entrusted to carry out the specific planning and design work. The design scheme is usually negotiated and determined by the government (or commissioned developers) directly with the designers. The citizens as the main beneficiary of the design result are only regarded as the object of preliminary researches and publication of consequences, but excluded from the current design and decision process. Furthermore, there is a restrictive relationship with benefits between the designer and the government (or developer) as the entrusting party, so they cannot fully represent the welfare of the public in the process.

As a rudiment of bottom-up exploration of public participation in urban design, the advocate of postmodern planning proposed the design paradigm based on pluralism, which is on the strength of grassroots people and communities (Sandercock 2003). Designers play a guide rather than a direct voice to help marginalized communities and groups to speak for themselves, build inclusive participation mechanisms and platforms, seek interest balance points and reach consensus through active consultation as well. Thus, a sustainable cooperative connection can be built between different social members and profit groups: a community with a shared future. To realize this community, it is necessary to change the existing binary single relationship form (Figure 2) and construct a new type of bidirectional relationship with pluralism (Figure 3).

\section{(1) A new relationship between government and public}

According to the new subject relationship, the one-way "Government" should be replaced by an interactive "Governance" in urban management. By improving the situation of unitary governance with excessive power and advocating social participation, the functions and roles of the city government are redefined at the whole social level, and the relationship between the authority and the civil society is reconstructed (Zhao 2013). At the level of urban design, the public engagement in the formulation of goals, design and selection of programs, and feedback from practices can ensure that the final scheme is consistent with different values and purposes of groups, which include ordinary citizens, public welfare organizations and private institutions.

\section{(2) The role of urban designers in the new relationship}

While, urban designers need to explore an ideal mode that mutual restriction and assistance coexisted between the public and the government, and between different urban groups. They can not only interpret the official voice to the residents but also be a loudspeaker to reflect the public wishes from the bottom. For the government, the designers are technicists who implement the strategic planning intention, and the experts who can consult on professional issues, too.

Although the official capacity is still overwhelming, from the one-way binary relationship which the government dominates and urban designers assist, to the pluralistic triangle relationship between the government, residents and designers, the power begins to gradually transit to down. To encourage multiple parties' engagement and decision-making is to rebuild the multi-subject relationship from the perspective of urban designers with multilateral cooperation as the goal. The balance of public interests and the distribution of decision power are the primary tasks among the relation remodel. 


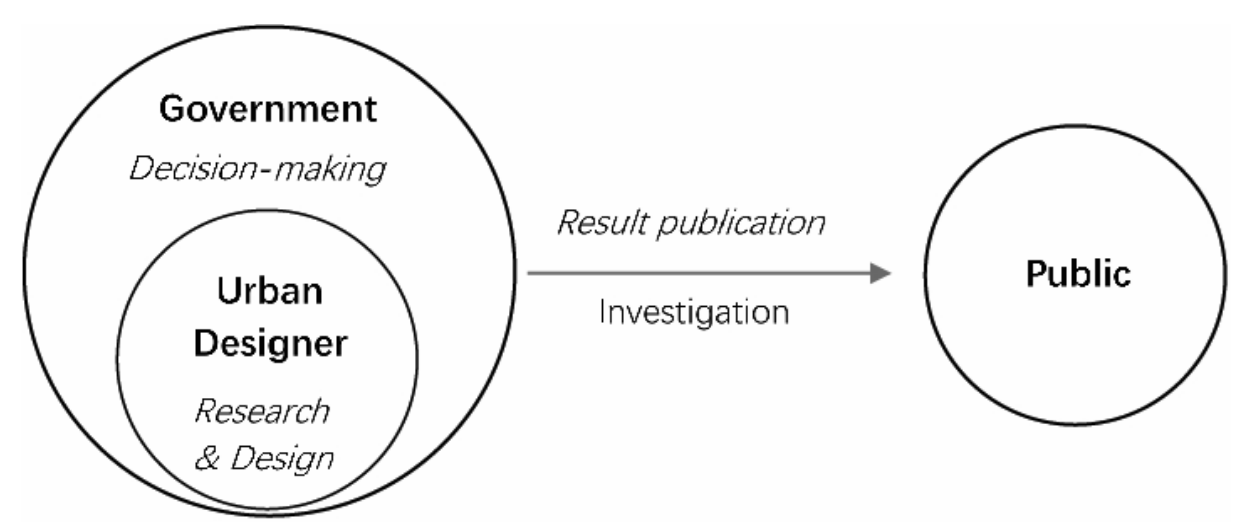

Figure 2. The one-way binary relationship of subjects in urban design process. Source: author drew.

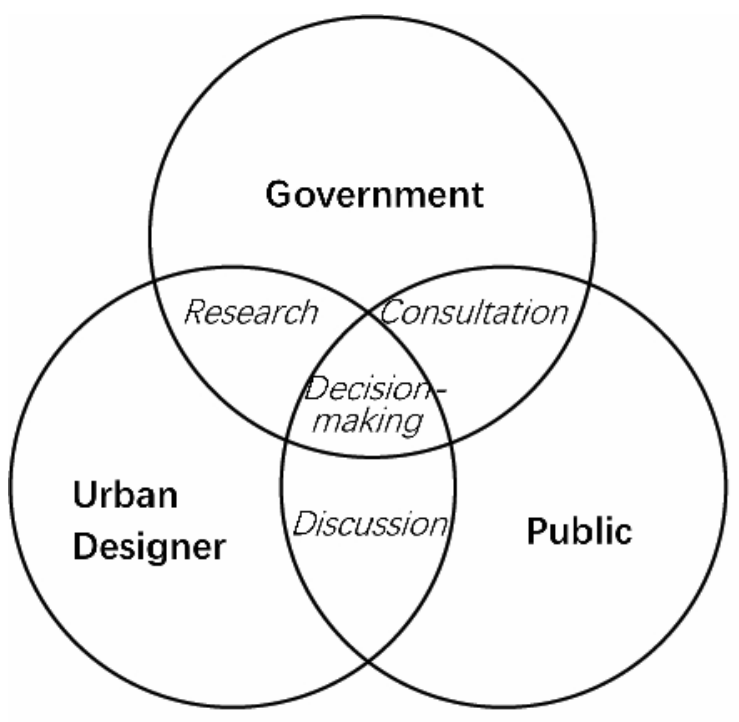

Figure 3. The pluralistic triangle relationship among subjects in urban design process. Source: Wang, 2006.

\section{2. Vertical research: The diversity of the "public" in community}

Multiple participation emphasizes the diversification of subjects, the essence of which is to establish an institutional form in the micro field. It can guide a large number of social forces to join in social governance and public decision-making process, which serves as a supplement for the single subject of the government on management (Qin and Duan 2015). The public, as a synonym of social power, is in diversity and asymmetry (Kang 2019), the members and their appeals are complex. Ignoring their differences will not only decrease the varieties of participants, but the single participation means can be also hard to apply to each member at the same time, thus the effectiveness of public participation is reduced greatly. Therefore, the urban design participation oriented by community needs to further clarify the role of public groups in the community scale. Finding out the key groups of community governance in China, which can provide direction and support for the multi-participation mode exploration of urban design with practical significance under the current national conditions. This paper will focus on key groups and organizations at the community level, which are mainly oriented towards the public interest, including neighbourhood 
committees, social service and university research groups, as well as civic voluntary organizations as potential participants.

\begin{tabular}{|c|c|c|c|c|}
\hline $\begin{array}{c}\text { Participating } \\
\text { channel }\end{array}$ & Public group & Member & Purpose & $\begin{array}{l}\text { Result of } \\
\text { selection }\end{array}$ \\
\hline \multirow{9}{*}{$\begin{array}{l}\text { Formal } \\
\text { channel }\end{array}$} & $\begin{array}{l}\text { Neighbourhood } \\
\text { committee }\end{array}$ & $\begin{array}{l}\text { Resident } \\
\text { representatives } \\
\text { (elected enthusiastic } \\
\text { individual by residents) } \\
\text { or public functionary }\end{array}$ & Public interest & Key group \\
\hline & \multirow{2}{*}{$\begin{array}{l}\text { Community self- } \\
\text { organization }\end{array}$} & Interest group & $\begin{array}{l}\text { Personal interest } \\
\text { (hobby) }\end{array}$ & Auxiliary group \\
\hline & & $\begin{array}{l}\text { Volunteer } \\
\text { organization: } \\
\text { enthusiastic citizens }\end{array}$ & Public benefit & Potential group \\
\hline & $\begin{array}{l}\text { Community } \\
\text { owners } \\
\text { committee }\end{array}$ & $\begin{array}{l}\text { House owners' } \\
\text { representatives } \\
\text { (elected enthusiastic } \\
\text { individual by house } \\
\text { owners) }\end{array}$ & $\begin{array}{l}\text { The interests of } \\
\text { specific groups }\end{array}$ & Auxiliary group \\
\hline & \multirow{4}{*}{ Civil organization } & $\begin{array}{l}\text { Private sector: } \\
\text { property companies, } \\
\text { etc. }\end{array}$ & $\begin{array}{l}\text { Personal interest } \\
\text { (Revenue) }\end{array}$ & Auxiliary group \\
\hline & & Social work agency & Public benefit & Key group \\
\hline & & $\begin{array}{l}\text { University research } \\
\text { institute }\end{array}$ & Public benefit & Key group \\
\hline & & Public media & Public benefit & Auxiliary group \\
\hline & $\begin{array}{l}\text { Community party } \\
\text { organization }\end{array}$ & $\begin{array}{l}\text { Appointed by } \\
\text { government }\end{array}$ & Public benefit & \\
\hline \multirow{2}{*}{$\begin{array}{l}\text { Informal } \\
\text { channel }\end{array}$} & \multirow{2}{*}{$\begin{array}{l}\text { Acquaintance } \\
\text { relationship }\end{array}$} & $\begin{array}{l}\text { Residents that have a } \\
\text { specific relationship } \\
\text { with officials }\end{array}$ & Personal interest & \\
\hline & & $\begin{array}{l}\text { Enthusiastic citizen } \\
\text { who carry out } \\
\text { community works }\end{array}$ & Public benefit & Key group \\
\hline
\end{tabular}

Table 6. Selection of important group involved in community building by formal or informal ways. Source: author edited.

As a community-level management organization with Chinese characteristics, neighbourhood committees are the main type of channel for residents to take part in political affairs. Their responsibilities are mainly to handle the public affairs and public welfare in the local community, organize self-governance activities 
for residents, and fully realize grassroots democracy through the election in the principle of selfgovernance. It can be seen that the neighbourhood committee is a transitional job between the government and the public, a key group under the supervision of both sides, but has less substantive administrative and decision-making power. The disappearing role, street office, is not accessible for general public and shoulders more official responsibility, whose support will bring obvious change to community by hearing from neighbouhood committee. Although community party organizations have similar roles and functions, they are appointed by the official department, which makes them lack the original motivation of participation and cooperation, and tends to deviate from the orientation of public interest. The voluntary organizations in communities mainly composed of enthusiastic citizens have strong self-organization and participation motivation. However, due to the complicated and small number of members that are mostly retired elderly people, it is difficult to form group strength, and still need to be cultivated and absorbed.

Society service organizations and university research teams also play an important character in community building. For example, the program "Open Your Space: Design Intervention in Siping Community", is a practical and creative space reconstruction carried out by the local university team and the Siping street office together. Meanwhile, the non-governmental organization, Dayu community building \& developing center rooted in the old residential areas of Shanghai, also establishes good cooperation with the neighbourhood committee and street office. They integrate the community resources on the fully respecting the residents' wishes, to find the profit points and introduce it to the market (the private sector) for sustainable operation. It is a diversified participation approach dominated by public welfare but still in the exploring stage, such organizations need to find a sustainable source of funds or operation style due to the non-profit principle.

As for auxiliary groups, who are helpful but not so necessary for themselves to participate in community affairs. For example, public media are good at advertising and supervising official behaviors by public opinions, but their public capacites determines that it is powerful role in city who needs pubilc attention, which means news in community may not be so attractive for broader citizens. So, participating in community building for public media are not so effective and essential.

Except for the formal organizational channels mentioned above, acquaintance relationship among residents in the commnuity, which are stronger than those in the western countries, is also an informal means of contact for citizen engagement. Relying on the enthusiastic representatives, such as building leaders and neighbourhood committee members, to carry out acquaintances work is an important way to naturally transform residents from non-enthusiastic into enthusiastic within the community. This approach is conducive to cultivate the participation awareness and community ties, enrich target groups, and effectively promote the community practice of participation in the urban design process.

\section{Innovative attempts to achieving multiple participation by community building in China}

So far, practice and thinking of community building in China are still in the early stage, it has been explored and transforming into Citizen Participation with several typical cities like Shanghai and Nanjing. In this stage, the common tendency is improving the physical environment, which means citizens and government can have a reasonable dialogue with a mutual target of better living quality. Although conflicts are evidently decreased owing to the coordination of the third party, the effort is not rewarded in the aspect of the social environment. The reason behind that is mainly because the reform of social institution is difficult to promote, and the social power is too weak to shake the official one, then bottom-up social movement 
hardly goes sustainably. According to that, coordinating for mutual vision became a key to cohere all parties and emphasize the principle role of community.

Advocating the value of social justice, diversity and inclusion, inclusive community is a world trend, setting in mainstream theories such as communicative planning and collaborative planning. Among those researches, Age-Friendly City was raised as a blueprint for human life in the future (WHO 2007), which raises the interests of researchers around the world. It has allocated many of propositions on one theme, age-friendly, to promote intergeneration interaction and attract more public attention, then mobilizing social resources to serve for building the inclusive community, even inclusive city. Many pieces of practice researches in China also notes that stressing the role of old people and children as a key group in community work, which would promote resource-mobilizing and activity-participating in neighbourhoods (Liu 2016; Xu et al. 2017; Wang 2013).

This chapter starts with practice cases to explore the practical path of community building for inclusive neighbourhoods in China.

\subsection{Representatives and modes of community building practice}

As Table 7 shows, it can be divided into three main modes according to their representative groups. Among those, the model of 'third party' has four branches, and three of them are explained below because of their non-for-profit purpose for promoting community environment simply. As a consequence, they are less affected by government and market at work, which means more trust can be built to contribute to more popular community activities. The most remarkable practice outcome for the recent 10 years in China, is Community Planner mode, which has been in an institutional operation supported by governmental departments and recognized by the public. The role of community planner as a facilitator is proved to be essential in the neighbourhood practices, such as community building, while spontaneous community activity and single driving by the government are both far from reaching the nature of community planning -- the growth of social capital (Zhao 2013). As for the second mode of NPO-oriented, university research institution is capable to provide knowledge support, while fieldwork is cherished experience for professional students, which achieve double-win for community and college. Community lab in San Siro, Milan, is a good example that the Polytechnic University of Milan has set a base site during a community regeneration program, attracting worldwide attention. At last, the social work agency is generally believed to have rich experience in organizing activities and incubating groups in the community. It plays a vital role in the subsequent phases of community building, like raising the consciousness of participation and operating, maintaining either physical outcome or social achievement in that program.

\begin{tabular}{|l|l|l|l|l|l|}
\hline \multicolumn{1}{|c|}{ Mode } & Representative & \multicolumn{1}{c|}{ Purpose } & Target Group & \multicolumn{1}{c|}{ Path } & \multicolumn{1}{c|}{ Example } \\
\hline $\begin{array}{l}\text { Governmen } \\
\text { t-led }\end{array}$ & $\begin{array}{l}\text { Community } \\
\text { planner team } \\
\text { hired by a } \\
\text { governmental } \\
\text { department }\end{array}$ & $\begin{array}{l}\text { for official } \\
\text { given } \\
\text { mission and } \\
\text { index }\end{array}$ & $\begin{array}{l}\text { general } \\
\text { residents }\end{array}$ & $\begin{array}{l}\text { a set of } \\
\text { community } \\
\text { planning master } \\
\text { plan }\end{array}$ & $\begin{array}{l}\text { Shanghai Urban } \\
\text { Planning \& Design } \\
\text { Research Institute } \\
\text { (SUPDRI): Wanli } \\
\text { Community, } \\
\text { Shanghai }\end{array}$ \\
\hline $\begin{array}{l}\text { Community } \\
\text {-led }\end{array}$ & $\begin{array}{l}\text { community self- } \\
\text { organization }\end{array}$ & $\begin{array}{l}\text { for } \\
\text { individual or }\end{array}$ & $\begin{array}{l}\text { specific } \\
\text { resident } \\
\text { group }\end{array}$ & $\begin{array}{l}\text { to establish a } \\
\text { self-governance } \\
\text { committee to }\end{array}$ & $\begin{array}{l}\text { Benefit } \\
\text { Association: } \\
\text { Cuizhuyuan }\end{array}$ \\
\hline
\end{tabular}




\begin{tabular}{|c|c|c|c|c|c|}
\hline & & $\begin{array}{l}\text { community } \\
\text { welfare }\end{array}$ & $\begin{array}{l}\text { (resident } \\
\text { representativ } \\
\text { e) }\end{array}$ & $\begin{array}{l}\text { negotiate with } \\
\text { neighbourhood } \\
\text { committee and } \\
\text { street office }\end{array}$ & $\begin{array}{l}\text { Community, } \\
\text { Nanjing }\end{array}$ \\
\hline \multirow{4}{*}{$\begin{array}{l}\text { Third Party- } \\
\text { led }\end{array}$} & $\begin{array}{l}\text { community } \\
\text { planner team } \\
\text { hired by } \\
\text { community }\end{array}$ & $\begin{array}{l}\text { for better } \\
\text { living quality } \\
\text { in } \\
\text { community }\end{array}$ & $\begin{array}{l}\text { specific } \\
\text { resident } \\
\text { group (focus } \\
\text { group) }\end{array}$ & $\begin{array}{l}\text { to conduct long- } \\
\text { term research } \\
\text { and practice of } \\
\text { community } \\
\text { building on site }\end{array}$ & $\begin{array}{l}\text { Community } \\
\text { planner: Pudong } \\
\text { Colorful } \\
\text { Community, } \\
\text { Shanghai }\end{array}$ \\
\hline & $\begin{array}{l}\text { university } \\
\text { research } \\
\text { institution }\end{array}$ & $\begin{array}{l}\text { for } \\
\text { academic } \\
\text { aim, like } \\
\text { learning } \\
\text { practice, } \\
\text { research, } \\
\text { etc. }\end{array}$ & $\begin{array}{l}\text { specific } \\
\text { resident } \\
\text { group }\end{array}$ & $\begin{array}{l}\text { professor and } \\
\text { student from } \\
\text { college located } \\
\text { in community for } \\
\text { one project, } \\
\text { organizing } \\
\text { community } \\
\text { activity and do } \\
\text { community } \\
\text { building practice }\end{array}$ & $\begin{array}{l}\text { Tongji University } \\
\text { College of Design } \\
\text { And Innovation: } \\
\text { Open Your Space: } \\
\text { Design } \\
\text { Intervention in } \\
\text { Siping } \\
\text { Community }\end{array}$ \\
\hline & social work agency & $\begin{array}{l}\text { for some } \\
\text { human- } \\
\text { oriented } \\
\text { principle }\end{array}$ & $\begin{array}{l}\text { vulnerable } \\
\text { group }\end{array}$ & $\begin{array}{l}\text { to incubate } \\
\text { community } \\
\text { group for social } \\
\text { activities }\end{array}$ & $\begin{array}{l}\text { Dayu community } \\
\text { building \& } \\
\text { developing } \\
\text { center: Xinhua } \\
\text { Neighborhood } \\
\text { Recreation }\end{array}$ \\
\hline & $\begin{array}{l}\text { commercial design } \\
\text { firm }\end{array}$ & $\begin{array}{l}\text { for } \\
\text { commercial } \\
\text { benefit } \\
\text { mainly }\end{array}$ & homeowners & $\begin{array}{l}\text { by holding } \\
\text { activities to } \\
\text { advertise paid } \\
\text { service and } \\
\text { product; carry } \\
\text { charitable event } \\
\text { for shaping } \\
\text { company }\end{array}$ & $\begin{array}{l}\text { Shui On Land- } \\
\text { Shanghai KIC } \\
\text { Garden }\end{array}$ \\
\hline
\end{tabular}

Table 7. Modes of the three parties in community building. Source: author drew.

\section{Brief Summary}

Through the above-summarized experience of community building practice, the three subject participants quoted above can be converted from "Government", "Public" and "Urban Designer" to the corresponding role in the communities like "Street Office \& Neighborhood Committee", "Resident" and "Technique Holder" with a central hub named community planner. Actually, the source of community planner can be anyone among those three parties, gathering as one team to work, whose responsibility is operator and facilitator, serving as a bridge to connect government and public, as well as professional and nonprofessional. As the initiator of this program who can allocate institutional resources, the official branch in street or community takes a role to guide, direct and supervise, proceeding community-building program. 
Then residents, as participants, provide consensuses of personal space experience to support reasonable and legal design, by their irreplaceable real perceiving living in this place and participating behaviour itself. The final subject, as a supporter, professional has technique support in design and construction, who has the specialized capacity to supply others along with operating, maintaining, and other follow-up services. Therefore, with the community planner as the facilitator, coordination that sharing right and benefit among those three parties shows complement existing relationships of multi-subjects in community building. (see Figure 4, the bottom part)

\begin{tabular}{|l|l|l|l|l|l|}
\hline \multicolumn{1}{|c|}{ Type } & Education Goal & \multicolumn{1}{c|}{ Value } & \multicolumn{1}{c|}{$\begin{array}{c}\text { Social } \\
\text { Mechanism }\end{array}$} & \multicolumn{1}{c|}{$\begin{array}{c}\text { Occupational } \\
\text { Feature }\end{array}$} & \multicolumn{1}{c|}{ Object } \\
\hline $\begin{array}{l}\text { Traditional } \\
\text { Urban } \\
\text { Planner }\end{array}$ & $\begin{array}{l}\text { professional- } \\
\text { oriented } \\
\text { (professor) }\end{array}$ & $\begin{array}{l}\text { emphasizing the } \\
\text { authority of } \\
\text { outcome }\end{array}$ & $\begin{array}{l}\text { monitoring- } \\
\text { oriented }\end{array}$ & $\begin{array}{l}\text { technique } \\
\text { standard }\end{array}$ & $\begin{array}{l}\text { elite- } \\
\text { oriented }\end{array}$ \\
\hline $\begin{array}{l}\text { Community } \\
\text { Planner }\end{array}$ & $\begin{array}{l}\text { general- } \\
\text { oriented } \\
\text { (generalist) }\end{array}$ & $\begin{array}{l}\text { emphasizing } \\
\text { process (real- } \\
\text { time planning) }\end{array}$ & $\begin{array}{l}\text { communicating } \\
\text {-oriented }\end{array}$ & service standard & $\begin{array}{l}\text { civilian- } \\
\text { oriented }\end{array}$ \\
\hline
\end{tabular}

Table 8. Comparison of Community Planner and Traditional Urban Planner. Source: Huang and Xu, 2013.

\subsection{Modes and strategies of multi-body participation in community building}

There is a report of several pieces of practice research about community building hosted by SUPDRI, whose reporter summarized four main elements in a support system of Coordinating to Participate in Cogoverning, including decision-making mechanism, implementation \& construction, fund operation, and human resource (Xi 2020). In this paper, the main perspective is to explore a practical mode in human resource aspect, which means the interaction of multiple principle roles and their capacity, by the way, strategies and suggestions are also mentioned on the other aspects.

\begin{tabular}{|l|l|l|l|l|}
\hline \multicolumn{2}{|l|}{} & $\begin{array}{l}\text { Decision-making } \\
\text { Mechanism }\end{array}$ & $\begin{array}{l}\text { Implementation } \\
\text { \& Construction }\end{array}$ & Fund Operation \\
\hline \multicolumn{1}{|l|}{$\begin{array}{l}\text { Street Office \& } \\
\text { Neighborhood Committee }\end{array}$} & +++ & + & ++ \\
\hline \multirow{4}{*}{$\begin{array}{l}\text { Technique } \\
\text { holder }\end{array}$} & $\begin{array}{l}\text { Community } \\
\text { Planner }\end{array}$ & ++ & $\begin{array}{l}++ \\
\text { (outsourcing project, } \\
\text { self-constructing or } \\
\text { co-constructing) }\end{array}$ & $\begin{array}{l}\text { (social fund, self- } \\
\text { investment or applying } \\
\text { official fund) }\end{array}$ \\
\cline { 2 - 6 } & $\begin{array}{l}\text { Agency } \\
\text { (oork }\end{array}$ & + & $\begin{array}{l}++ \\
\text { (self-constructing, } \\
\text { outsourcing project) }\end{array}$ & $\begin{array}{l}\text { (applying official fund, } \\
\text { seeking social } \\
\text { investment) }\end{array}$ \\
\cline { 2 - 5 } & $\begin{array}{l}\text { University } \\
\text { Research } \\
\text { Group }\end{array}$ & ++ & $\begin{array}{l}++ \\
\text { (student practice) }\end{array}$ & $\begin{array}{l}+ \\
\text { (free labor, low cost) }\end{array}$ \\
\hline
\end{tabular}




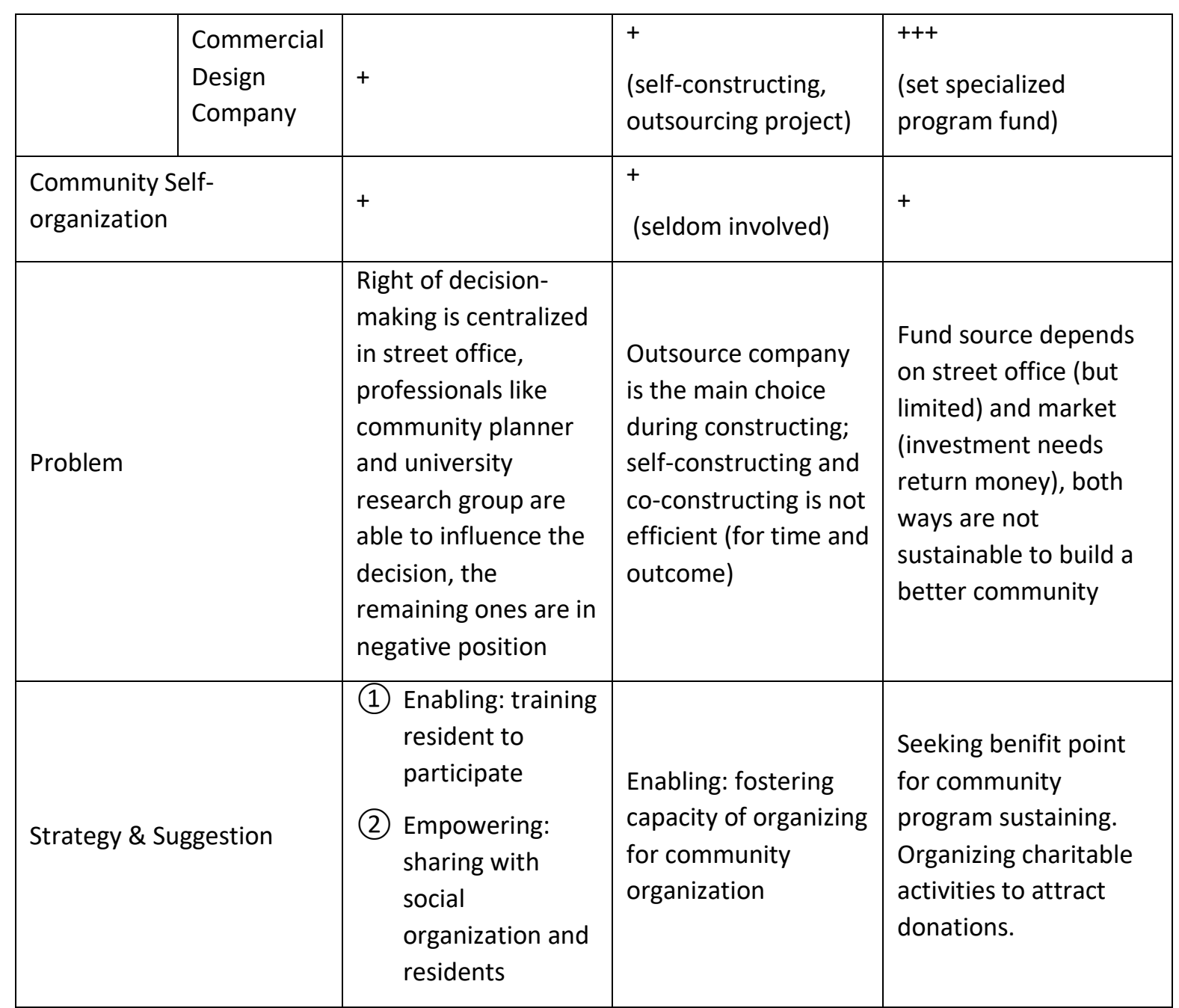

(Legend: + weak participation, ++ mediate participation, +++ strong participation.)

Table 8. Evaluation of the three parties' participating situation in the supporting system for community building. Source: author edited.

\section{(1) Three-level strategy to promote community participation}

Regarding that Chinese situation of participation has been talked above, three-level strategy to stimulate community participation can be listed, including engaging, enabling and empowering, covering the whole process of a community-building program:

(1) Engaging

- $\quad$ Reaching Consensus: community planner work as a facilitator to coordinate with the three parties for consensus.

- Establishing Specialized Committee: to set up a trusted platform for joint action

- $\quad$ Launching Workshop: organizing diverse activities to provide more opportunities and paths to exchange ideas, and taking an advantage of online social networks.

(2) Enabling 
- Fostering the Organizing Capacity of Community Organization: cultivating social organization with the help of official resources in neighbourhoods, 1> street office and community collaborate with the local college to set community class, where teaching, learning, and practice in one place. $2>$ developing community self-organization: to set up and develop interest groups relevant to community building.

- Cultivating Community Planners: they can come from the professional school or grow in social practice, and the second path will give training chances and work positions for potential talent who is discovered from the community.

- Equipping Participating Capacity for Residents: which gained from the mature community planner and community organization by diverse community activities.

(3) Empowering

- Empowering Social Organization: the agency right that represents the street or community to manage and operate the community building program.

- Sharing More Right for Residents to Choose, Participate and Speak, even Make Decision: to provide more opportunity and one trusted platform, besides, modifying mechanisms to guarantee those rights and benefits. Some paths like launching a self-governing committee to join the table to determine community affairs, and another one is selected from the community or hired community planner in society to represent those residents.

(2) Interacting Mode of Multi-bodies Participating in Community Building - Roles and Relationship of Multi-age Groups in Building Inclusive Community

To select key characters in the community, it may not be limited in one scale, which means scale ranged ought to be extended. In the lower scale, family, four age groups are figured to proof that individual is related to the broader environment as a family. Then, professionals are introduced in the scale of "city", listing several overlapping areas with those age groups. Through this model, it can be found that old people and children have less social influence, regarded as a vulnerable group on most occasions, but still are the focus groups in the community building program. This phenomenon is determined by the human-oriented principle that all designers believe, and ageing society, as well as birth-control policy, is the other reason. Among young people, as the main labour source, college students and volunteers can be absorbed as an important group devoted to community activities. While the middle age group, as man influencer in society, equipped with rich social resource and advanced technique. So, community planner must allocate and utilize those enthusiastic people in multi-age groups through accumulating effect, as the elite in society and able person in neighbourhoods. (see Figure 4.) 


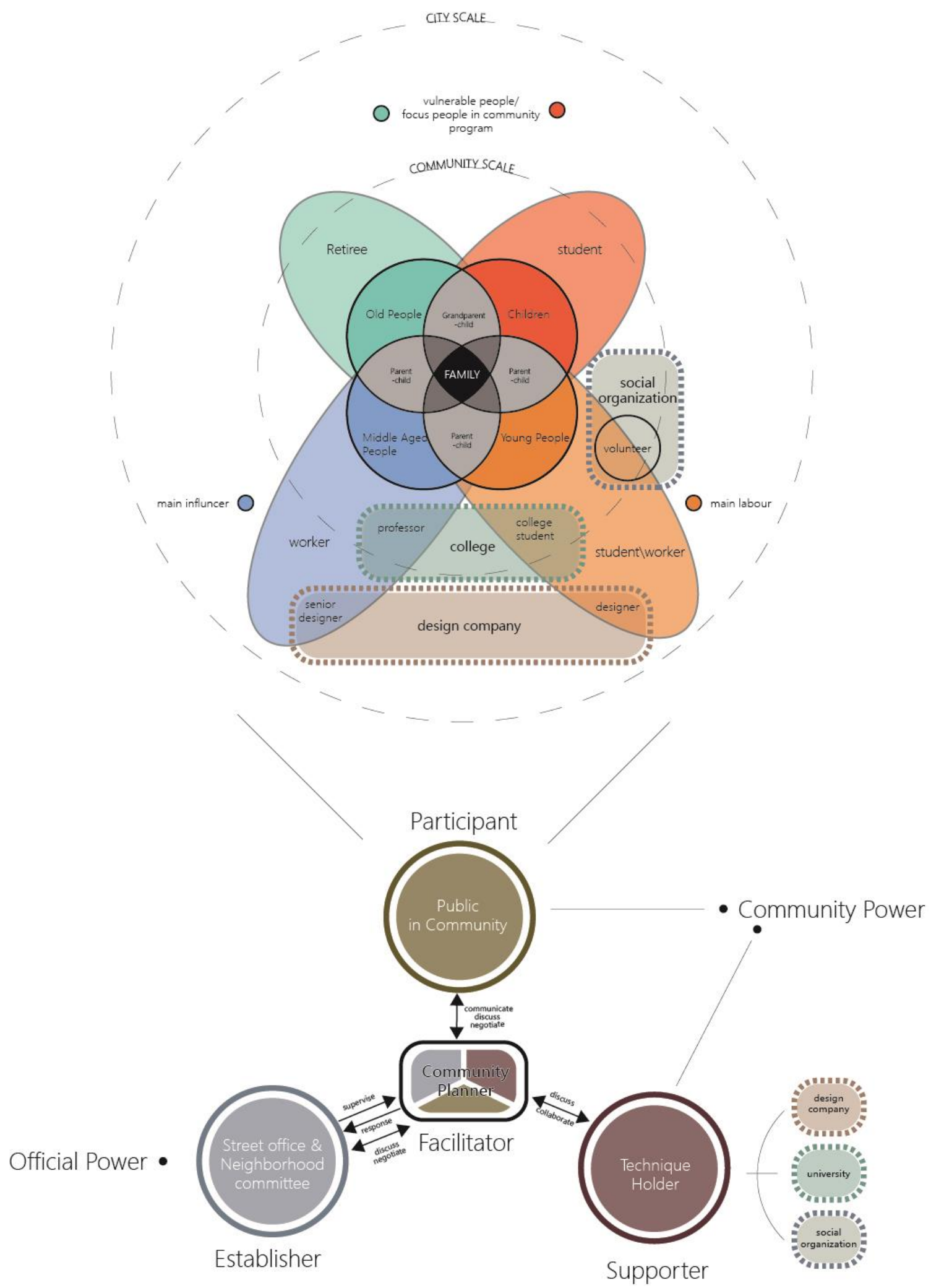

Join Force For One Vision- Inclusive Community

Figure 4. Multi-age participation mode of in community building and new relationships and roles of the three parties in commnunity. Source: author drew. 
Thus, to build an inclusive community, the impact of the principal roles like old people and children should be stressed out in process of community building, they will motivate the other age groups to join community activities and affairs. Family is also an energy point that can attract and gather social resources from community even city to serve the neighbourhood. Then, human resources are allocated to strengthen the power of the community and its subject status in the community building program. Finally, the mutual vision of inclusive community will be pursued by the joint effort of the three parties in community building.

\section{Conclusion}

Through researching international tendency and domestic situation of multiple participation, as well as multiple principal roles, the conclusion reaches that community building is a practicable path for inclusive neighbourhoods. As a result, the interacting model of multi-bodies and three-level strategies are proposed. Multiple participation practice in the community is directed by family-motivating in the process, which promotes multi-age take part in the community building. Although more latest practice cases should be supplemented for this practice research, it is innovative thinking also helps following practices. In the future, coordinating and co-governing will become the mainstream idea, and better community life will be created by the joint efforts from multiple parties with community planners' facilitating.

\section{References}

Arnstein, S.R. (1969). A Ladder of Citizen Participation. Journal of the American Institute of Planners, 35(July), pp.216-224.

Hao, J. (2007). Analysis on the Barriers and Causes in Development of Public Participation in Chinese Urban Planning. Modern Urban Research, 9, pp.21-25.

Hao, Y. (2016). The Concept and Method Research of the Community Based Urban Design: To Old Residential Community, Yuzhong District, Chongqing as an Example. Chongqing University.

Huang, L. and Xu, J. (2013). The Value Basis and Role Building of Community Planner Institution. Planners, 29(9), pp.11-16.

Kang, Y. (2019). The Balance and Reconstruction of Multi-participant Relations in Urban Renewal: Based on the Consultative Participation Mechanism of Interaction. Xiamen University.

Liu, Y. (2016). Community Gardening: A New Approach to Free More Micro Urban Space. Public Art, (7), pp.10-15.

Long, Y. (2004). Communicative Planning and Public Participation. Public Participation, 23(1), pp.73-77.

Qin, T. (2015). New development of environmental governance system: from unidimensional governance to multiple participation. China Ecological Civilization, (4), pp.72-75.

Sandercock, L. (2003). Towards Cosmopolis: Planning for Multicultural Cities. Chichester, England: J. Wiley.

Sun, S. and Yin, Y. (2004). The Evolution of the Basic Theories of Public Participation in Urban Planning in Western Countries. Urban Planning Overseas, 19(1), pp.14-20.

Wang, L. (2013). A Research about Elite and the Construction of Participatory Community: Case of Cuizhuyuan Community in Nanjing. Nanjing University. 
Wang, K. (2006). Study on Process Supporting System of Urban Design. Zhejiang University.

World Health Organization (2007). Global age-friendly cities: A guide. World Health Organization.

Xi, W. (2020). Growing in Diversification, Planning and Practice of Community life Circle.

Xu, L. et al. (2017). Practice and Reflection on Community Micro-regeneration under the Background of Innovative Social Governance: Two Practice Cases by 408UDR Lab. Urban and Rural Planning, (4), pp.43-51.

Yu, X. and Zhang, D. (2002). Communitarianism: The Trend of Pubic Ethic. Journal of Shanghai Jiaotong University (Philosophy and Social Science), 10(1), pp.31-35.

Zhao, M. (2013). A Discussion on Community Building and Community Preference in City Planning. Planners, 29(9), pp.5-10.

Zhao, W. (2013). Institutional Foundation of Community Planning and the Role of Community Planner. Planners, 29(9), pp.17-21.

Zhou, J. et al. (2017). From Game to Balance: Values Analysis of Public Participation of Chinese and Western in Urban Renewal. Urban Development Studies, 24(2), pp.84-90. 